\title{
锡烯的研究进展
}

\author{
钱冬，贾金锋* \\ 上海交通大学物理与天文系, 上海 200240 \\ *联系人, E-mail: jfjia@sjtu.edu.cn
}

2016-06-08 收稿, 2016-07-27 修回, 2016-07-27 接受, 2016-10-08 网络版发表

\begin{abstract}
摘要石墨烯研究的巨大成功推动了二维晶体材料研究领域的蓬勃发展, 和碳同族的IV族元素组成的具有类 石墨烯结构的二维晶体材料受到了广泛的关注，其中由锡元素组成的锡烯晶体由于其优异的物理特性成为研究的 热点之一。理论计算表明锡烯是一种大能隙的量子自旋霍尔效应绝缘体, 还能够转化为二维的拓扑超导体. 锡烯 晶体在电子无耗散输运、自旋流产生、高性能热电、光电器件、拓扑量子计算等方面都具有重要的潜在应用价值. 本文针对最近几年来锡烯的研究进展进行简要的综述. 首先简单描述为什么锡烯晶体具有特殊的物理特性, 然后 介绍锡烯理论研究的进展以及最近利用分子束外延技术在锡烯晶体薄膜制备方法取得的突破，最后对今后可能的 实验研究方向和内容进行了展望.
\end{abstract}

关键词锡烯, 大能隙, 量子自旋霍尔效应绝缘体, 分子束外延

自从在实验上实现石墨烯 (graphene)的制备以 来, 二维材料的研究受到了极其广泛的关注. 石墨烯 在电子结构、机械强度、稳定性等多个方面都表现出 独特的性能. 在电子输运方面, 虽然石墨烯具有非常 大的载流子迁移率, 但是其本身是个零能隙的半导 体, 在传统半导体应用领域受到很多限制. 另一方 面, 在最初的量子自旋霍尔效应 (也称为二维拓扑绝 缘体)理论研究中, 石墨烯是第一种被预言的实验系 统 ${ }^{[1]}$. 量子自旋霍尔效应材料的二维体电子态具有能 隙, 是一种绝缘体 (半导体). 特别有意思的是, 在量 子自旋霍尔效应绝缘体的一维边缘存在一种特殊的, 且受到时间反演对称性保护的金属性边缘态. 该边 缘态中的电子具有自旋-动量锁定的特性, 也就是说 沿确定方向运动的电子其自旋方向也是严格确定的, 沿着相反方向运动的电子, 其自旋方向严格相反. 自 旋-动量锁定的特性使得电子能够在一维边缘上实现 无耗散的输运 ${ }^{[2]}$, 也可以用于实现纯自旋流. 量子自 旋霍尔效应体系在未来超低能耗的电子学和自旋电
子学方面可能有非常重要的应用价值. 实验上, 因为 构成石墨烯的碳是轻元素, 本征的自旋轨道耦合作 用非常小，导致由自旋轨道耦合形成的半导体能隙 只有微电子伏特量级, 远远小于实验分辨能力. 虽然 基于石墨烯的理论预言并没有被实验所证实，但是 这开创了量子自旋霍尔效应研究的先河. 现在实验 上获得证实的量子自旋霍尔效应体系是 $\mathrm{HgTe} / \mathrm{CgTe}$ 和 $\mathrm{InAs} / \mathrm{GaSb}$ 量子阱系统 ${ }^{[3 \sim 5]}$, 体能隙的大小在毫电 子伏特量级, 离实际应用还有很大一段距离, 探索更 大能隙的量子自旋霍尔效应材料成为二维材料理论设 计和实验探索的一个重要方向. 受石墨烯结构的启发, 近年来人们对具有类似石墨烯结构的其他IV族元素 二维材料的结构稳定性、电子能带结构以及拓扑态特 性开展了一系列的研究. 在IV族元素中有基于硅的硅

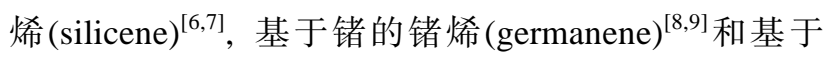
锡的锡烯(stanene $)^{[10 \sim 12]}$ 等. 在这些新材料体系中, 锡 烯有最大的自旋-轨道耦合效应, 能够产生超过 100 $\mathrm{mV}$ 以上的能隙, 并且具有较丰富的可调控性, 成为

引用格式: 钱冬, 贾金锋. 锡烯的研究进展. 科学通报, 2016, 61: 3252-3257 Qian D, Jia J F. Recent progress in the study of stanene (in Chinese). Chin Sci Bull, 2016, 61: 3252-3257, doi: 10.1360/N972016-00681 
探索基于大能隙量子自旋霍尔效应器件的理想系统 之一 ${ }^{[13]}$. 本文围绕锡烯薄膜的理论和实验发展, 介 绍最近几年来在锡烯理论和实验研究领域的一些最 新进展.

\section{1 锡烯理论研究进展}

石墨烯中, 碳原子因为电子轨道的 $\mathrm{sp}^{2}$ 杂化而形 成蜂窝状平面结构. 锡原子的电子轨道只能形成和 硅类似的 $\mathrm{sp}^{3}$ 杂化, 没办法形成完全平面结构的原子 点阵. 由 $\mathrm{Sn}$ 原子构成的最薄的原子点阵是一种具有 低度翘曲(low-buckled)的类蜂窝状结构, 如图1所示. 图1(a)是俯视图. 锡烯原子在同一个平面的投影形成 蜂窝状点阵结构. 图1(b)是侧视图. 可以看到, 在锡 烯结构中两层原子形成一种尧曲的结构, 两层原子 的高度差在 $1 \AA$ 左右. 2011 年, 原中国科学院物理研 究所姚裕贵课题组 ${ }^{[10]}$ 对具有翅曲结构的单层硅烯、锗 烯和锡烯的低能电子结构进行了详细计算和分析, 指出这些系统中存在能带反转现象, 都应该是量子 自旋霍尔效应体系. 同时, 计算结果表明大原子序数 结合晶格的尧曲结构使得这些系统的自旋轨道耦合 效应相比于石墨烯而言大大增强, 体能隙比石墨烯 要大好几个量级, 其中锡烯的体能隙最大. 2013年, 斯坦福大学张首晟课题组 ${ }^{[11]}$ 利用第一性原理计算对 锡烯薄膜及其化学修饰进行了细致研究. 如图2所示, 锡烯存在由 $\mathrm{p}_{\mathrm{z}}$ 轨道构成的悬挂键, 化学上可以对这些 悬挂键进行调控. 研究发现, 如果用氟、氯、碘等原 子来饱和悬挂键, 能够保持拓扑性质不变, 同时还能
把体能隙增加到 $300 \mathrm{meV}$ 以上. 虽然真正决定无耗散 输运的条件应该是相干散射长度, 但是远大于室温 的大能隙是一个必需的前提条件. 如果用氢原子来 饱和悬挂键, 锡烯的拓扑特性就会改变. 进一步的研 究表明, 如果利用悬挂键对表面修饰的锡烯进行电 子掺杂, 有可能将锡烯转变成二维的拓扑超导体, 从 而成为研究拓扑量子计算的载体 ${ }^{[14]}$. 如果只对锡烯 的一半悬挂键进行钝化, 理论上还有可能实现超过 液氮温区的量子反常霍尔效应 ${ }^{[15]}$, 这将大大增强反 常量子效应实用的可能性. 这些奇特的量子现象对 未来的量子信息和量子器件发展都具有重要的意义. 另外，第一性原理计算也预言，锡烯也有可能具有更 加复杂的哑铃状原胞结构 ${ }^{[16]}$. 哑铃状结构的锡烯和

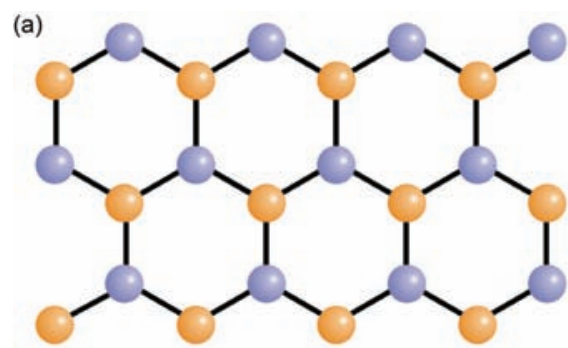

(b)

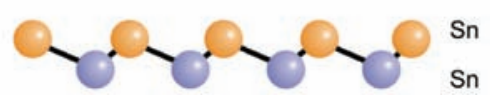

图 1 锡烯的原子结构图. (a) 俯视图, 类似于石墨烯的蜂窝状原子 点阵结构; (b) 侧视图, 两层原子形成翅曲结构

Figure 1 Atomic structure of stanene. (a) Top view. It shows honeycomb-like structure in analogy to graphene; (b) side view, two atomic layers form low-buckled structure (a)

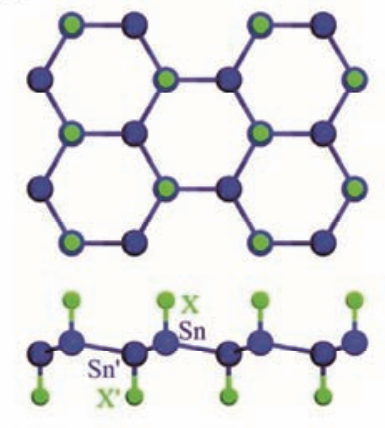

Decorated stanene

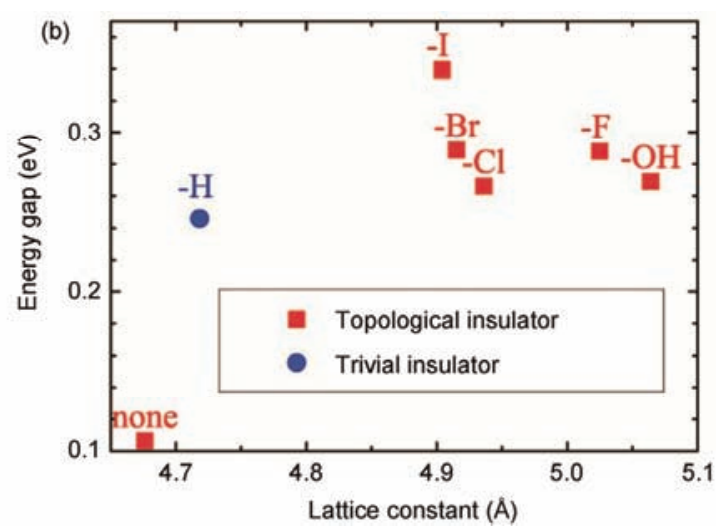

图 2 锡烯薄膜的化学修饰. (a) 对锡烯的悬挂键进行化学修饰的原子结构示意图; (b) 利用不同元素进行化学修饰后, 锡烯薄膜最稳定的晶格 常数、体能隙以及拓扑特性的关系图

Figure 2 Chemical decoration of stanene. (a) Atomic structures of decorated stanene; (b) energy gap as a function of the lattice constant with various chemical decorations 
尧曲型结构锡烯的拓扑特性是一致的, 也具有 100 $\mathrm{meV}$ 量级的能隙.

\section{2 锡烯实验进展}

理论计算表明锡烯具有优良的特性, 但是在实 验上实现锡烯的制备有很大的挑战性. 室温下稳定 存在的锡具有立方晶系的晶体结构, 被称为白锡, 白 锡表现出良好的金属性. 除了白锡以外, 锡还存在另 外一种亚稳相结构, 该亚稳相具有金刚石型原子结 构, 被称作灰锡, 灰锡是一种半导体. 锡烯可以看作 是由灰锡沿着立方对角线方向 (<111>方向)的 2 个相 邻原子层变化而来. 但是, 体材料灰锡只能够在低温 下稳定存在, 因此在石墨烯以及其他二维材料中常 用的机械或者化学剥离、化学气相沉积等方法都没办 法获得锡烯. 最近有印度Saxena等人 ${ }^{[17]}$ 在 arxiv上称 利用激光照射的办法, 在溶液里面获得一些多层锡 烯纳米材料, 实验结果非常初步, 有待验证. 普遍认 为, 类似于硅烯和锗烯, 在单晶基底上利用分子束外 延的方法制备锡烯薄膜可能是一种比较合适的方法. 从晶格匹配的角度来看, 半导体基底锑化铟 $(\mathrm{InSb})$ 和 灰锡的晶格大小非常接近. 在过去十几年里, 在 InSb 单晶基底上也的确已经成功外延生长出比较厚的灰 锡薄膜 ${ }^{[18 ~ 20]}$. 但是, 迄今为止还没有任何研究组能 够在 $I n S b(111)$ 基底上实现单层或者几层锡烯薄膜的 制备. 2015年, 本研究组 ${ }^{[21]}$ 利用分子束外延技术第一 次在半导体三碲化二铋 $\left(\mathrm{Bi}_{2} \mathrm{Te}_{3}\right)(111)$ 表面实现了单层 的锡烯薄膜的生长. 如图3(a)所示, 外延单层锡烯薄 膜表面呈现出六角形原子结构, 面内晶格常数和基 底相同. 细致的研究表明, 制备的锡烯薄膜的确具有 低度翅曲的双原子层结构. 图3(b) 是 $\mathrm{Bi}_{2} \mathrm{Te}_{3}(111)$ 表面 锡烯薄膜生长的原子结构示意图. 能带结构测量结 合第一性原理计算表明锡烯薄膜的悬挂键被饱和. 如图3(c)所示, 在布里渊区边界 $\mathrm{M}$ 点存在非常大的能 隙. 由于和基底存在电荷转移, 外延的锡烯薄膜在布 里渊区中心 $\Gamma$ 点附近存在费米面, 表现出金属性. 该 工作第一次从实验上证明具有翅曲状结构的锡烯薄 膜在基底上是可以稳定存在的. 锡烯薄膜的实验 制备成功, 为研究锡烯薄膜可能的特殊物性打开了 大门.

\section{3 展望}

锡烯的实验制备相比石墨烯而言要困难得多,
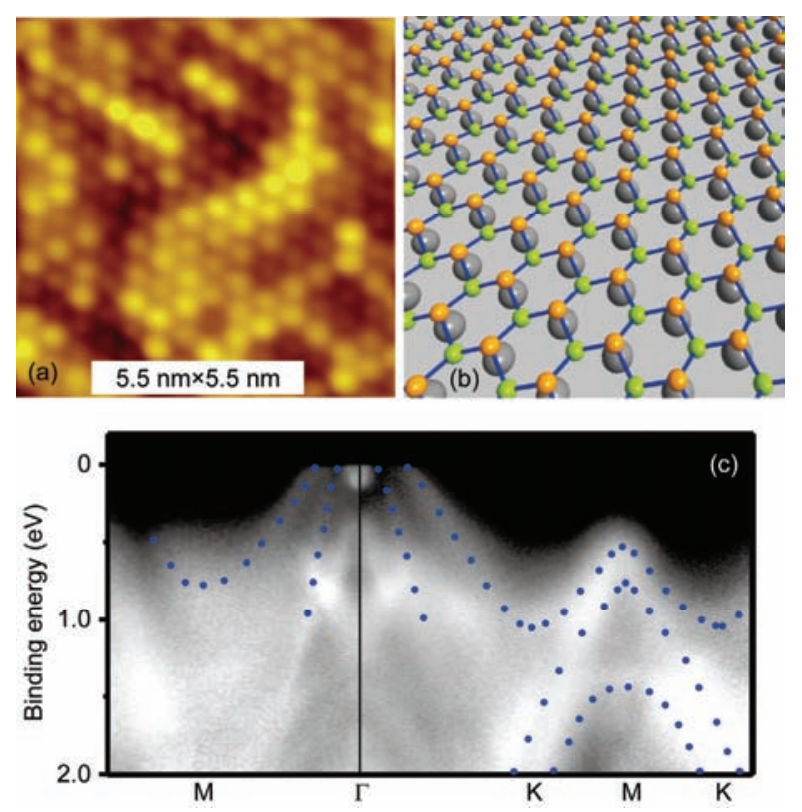

图 3 锡烯薄膜的原子和电子结构. (a) 锡烯薄膜表面原子结构; (b) 在 $\mathrm{Bi}_{2} \mathrm{Te}_{3}$ 表面锡烯原子结构示意图. 橙色和绿色球表示 $\mathrm{Sn}$ 原子, 灰色 球表示 $\mathrm{Te}$ 原子; (c) 测量的锡烯/ $\mathrm{Bi}_{2} \mathrm{Te}_{3}(111)$ 薄膜电子能带结构. 蓝色 点线表示来自于锡烯的能带 ${ }^{[21]}$

Figure 3 Atomic and electronic structures of stanene film. (a) Atomic structure on the surface of stanene; (b) atomic model of stanene on $\mathrm{Bi}_{2} \mathrm{Te}_{3}$. Orange and green balls are Sn atoms. Grey balls are Te atoms; (c) experimental band structures of stanene $/ \mathrm{Bi}_{2} \mathrm{Te}_{3}(111)$. Blue dotted lines are the bands from stanene ${ }^{[21]}$

在 $\mathrm{Bi}_{2} \mathrm{Te}_{3}$ 基底上分子束外延成功引发了众多的研究 热情. 其中如何获得大面积和高质量的锡烯薄膜成 为研究关注的焦点之一. 在实验上, 暂时还没有研究 组报道如何在现有的实验基础上得到提高. 理论方 面, 已经有研究组提出有望在实验获得验证的设想. 例如, 最近的第一性原理计算详细探讨了是否可以 在 $\operatorname{Ag}(111)$ 基底上实现大面积锡烯制备的可能性 ${ }^{[22]}$. $\operatorname{Ag}(111)$ 基底是制备硅烯的常用基底，系统的计算表 明, 在 $\operatorname{Ag}(111)$ 基底上锡烯仍然能够保持低度尧曲的 晶体结构, 虽然锡烯和 $\mathrm{Ag}$ 有非常严重的电子杂化. 和 $\mathrm{Bi}_{2} \mathrm{Te}_{3}$ 基底相比, $\mathrm{Ag}(111)$ 基底有一个优点, 由于外 延锡烯薄膜的高度和 $\mathrm{Ag}$ 基底的台阶高度非常接近, 因此有望获得连续的大面积的锡烯薄膜. 在硅烯研 究中, 已经有研究组通过表面保护以及基底溶解的 办法获得近自由的硅烯薄膜 ${ }^{[23]}$, 类似的方法也有可 能应用于锡烯薄膜中, 获得近自由的锡烯薄膜, 如果 能够在实验上实现这一步, 那么就可能对锡烯的电 子输运特性进行详细的研究.

锡烯的 $\mathrm{sp}^{3}$ 杂化轨道决定了其上下两个表面都具 
有悬挂键. 前期的理论研究已经表明通过对悬挂键 的修饰, 能够大大增加能隙. 其中氢饱和会改变锡烯 的拓扑特性, 将锡烯变成一个普通的半导体. 这种氢 饱和的锡烯被称作锡烷 (stanane). 实验上获得锡烯外 延薄膜之后, 有研究组根据第一性原理计算对锡烷 的电子特性进行了详细研究 ${ }^{[24]}$. 结果表明锡烷是一 种能隙为 $1 \mathrm{eV}$ 的二维半导体, 具有较大的载流子迁 移率, 在可见光和红外区域有很大的光吸收能力, 在 电子学和光电器件方面有非常好的潜在应用价值. 对于外延生长在基底上的锡烯, 在超高真空环境下, 实验上完全有可能利用氢吸附对悬挂键进行饱和, 从而实现理论上的锡烷构型. 另一方面, 只有一个表 面进行氢饱和的半氢化锡烯也呈现出有趣的特性 ${ }^{[25]}$. 和半氢化的石墨烯和硅烯类似, 第一性原理计算表 明半氢化的锡烯能够呈现出长程铁磁序, 且具有较 大的磁矩 (约 1 个玻尔磁子), 计算的居里温度要高于 硅烯 $(>120 \mathrm{~K})$, 长程铁磁性随晶格常数变化很小, 这 一点对于外延生长的薄膜尤为重要, 现在使用的 $\mathrm{Bi}_{2} \mathrm{Te}_{3}$ 基底相对于自由的锡烯, 晶格常数是压缩的.

前期的理论研究认为如果能把锡烯变成超导, 就有可能实现拓扑超导态, 并有望在其中实现马约 拉娜费米子, 用于拓扑量子计算 ${ }^{[14]}$. 锡烯薄膜实验 制备实现以后, 有理论研究组探讨了如何通过可能 的实验将锡烯薄膜转变成超导体 ${ }^{[26]}$. 如果只是考虑 电声子耦合诱发超导, 锡烯薄膜的载流子浓度不够, 需要进行额外的电子掺杂. 第一性原理计算表明, 如 果对锡烯薄膜进行锂或者钻元素掺杂, 就能够大大 提高载流子浓度. 通过计算掺杂之后的电声子耦合 强度, 理论计算预言超导温度能够在 $1 \mathrm{~K}$ 左右. 这个 温度虽然比体材料的白锡低, 但是完全在现有的低 温扫描隧道显微镜可以达到的实验温度以内, 因此 通过超高真空原位锂或者钻元素的掺杂来研究锡烯 薄膜可能的超导特性, 将是今后实验研究一个非常 有意思的方向.

锡烯除了电学特性以外, 在热学特性上也有其
特殊之处. 锡烯薄膜实验实现之后, 有理论研究组针 对其热传导特性开展了研究 ${ }^{[27,28]}$. 第一性原理计算 结合声子玻尔兹曼传输方程研究了锡烯晶格的热导 率. 计算结果表明锡烯的晶格热传导率远小于其他 的二维材料, 只有 $11.6 \mathrm{~W} / \mathrm{mK}$. 而硅烯的热导率是 26 $\mathrm{W} / \mathrm{mK}^{[29]}$, 单层 $\mathrm{MoS}_{2}$ 的热导率是 $34.5 \mathrm{~W} / \mathrm{mK}^{[30]}$. 低热 导率表明锡烯是一种良好的热电材料, 这可能对其 实现基于拓扑特性的高热电性能提供支撑 ${ }^{\left[{ }^{9]}\right.}$. 从实验 上研究锡烯薄膜可能的热传输特性是检验拓扑特性 相关的热电性能的出发点.

锡烯作为一种大能隙的量子自旋霍尔效应体系, 边缘态的电子输运问题是最关键的问题. 现在制备 成功的锡烯薄膜因为和基底之间的相互作用, 表现 出的是金属性，并不是绝缘体或者半导体. 要想进一 步研究锡烯的边缘态物理特性, 最大的挑战是如何 在绝缘基底上制备出近自由的锡烯薄膜. 受到外延 生长的实验启发, 最近有一系列新的理论文章探讨 可能的基底, 从理论上预言了一些比较合适的基底 材料。第一性原理计算表明，在半导体 $\mathrm{SrTe}$ 或者 $\mathrm{BaTe}$ 以 $\mathrm{Te}$ 原子层为终止面的(111)面上外延生长锡烯 薄膜, 就能够保持其绝缘性和大能隙的拓扑特性 ${ }^{[31]}$. 另外, 也有研究组提出在半导体 $\mathrm{InSe}$ 或者 $\mathrm{GeTe}$ 表面 也有可能实现绝缘体的锡烯生长 ${ }^{[32]}$. h-BN和AlN的再 构表面上实现绝缘锡烯薄膜的制备也被进行了细致 的理论探讨 ${ }^{[33]}$. 可以说, $\mathrm{Bi}_{2} \mathrm{Te}_{3}$ 表面锡烯薄膜外延成 功是锡烯实验研究迈出的第一步, 接下来需要在更 多可能的基底上进行探索. 未来基于锡烯的拓扑量 子态研究依赖于绝缘锡烯薄膜的实验突破. 从最近 的理论结果来看, 材料设计和计算结果都非常好, 但 在实验上还是存在较大的挑战. 理论上建议的上述 半导体基底，到现在为止并没有成熟的制备方法来 获得原子级平整的表面, 实验上需要首先解决基底 的问题，然后才能探索锡烯的制备问题. 锡烯作为一 种特殊的二维结构, 具有令人激动的量子特性, 对它 的实验研究还将是任重道远.

\section{参考文献}

1 Kane C L, Mele E J. Quantum spin hall effect in graphene. Phys Rev Lett, 2005, 95: 226801

2 Qi X L, Zhang S C. Topological insulators and superconductors. Rev Mod Phys, 2011, 83: 1057

3 König M, Wiedmann S, Brüne C, et al. Quantum spin hall insulator state in HgTe quantum Wells. Science, 2007, $318: 776$

4 Knez I, Du R R, Sullivan G. Evidence for helical edge modes in inverted InAs/GaSb quantum wells. Phys Rev Lett, 2011, $107:$ 136603 
5 Du L, Knez I, Sullivan G, et al. Robust helical edge transport in gated InAs/GaSb bilayers. Phys Rev Lett, 2015, 114: 096802

6 Vogt P, Padova P D, Quaresima C, et al. Silicene: Compelling experimental evidence for graphene like two-dimensional silicon. Phys Rev Lett, 2012, 108: 155501

7 Liu Z L, Wang M X, Xu J P, et al. Various atomic structures of monolayer silicene fabricated on $\operatorname{Ag}(111)$. New J Phys, 2014, 16: 075006

8 Dàvilla M E, Xian L, Cahangirov S, et al. Germanene: A novel two-dimensional germanium allotrope akin to graphene and silicene. New J Phys, 2014, 16: 095002

9 Bianco E, Butler S, Jiang S S, et al. Stability and exfoliation of germanane: A germanium graphene analogue. ACS Nano, 2013, 7: 4414

10 Liu C C, Jiang H, Yao Y G. Low-energy effective Hamiltonian involving spin-orbit coupling in silicene and two-dimensional germanium and tin. Phys Rev B, 2011, 84: 195430

11 Xu Y, Yan B H, Zhang H J, et al. Large-gap quantum spin Hall insulators in tin films. Phys Rev Lett, 2013, 111: 136804

12 Zhang G F, Li Y, Wu C J. Honeycomb lattice with multiorbital structure: Topological and quantum anomalous Hall insulators with large gaps. Phys Rev B, 2014, 90: 075114

13 Xu Y, Gan Z, Zhang S C. Enhanced thermoelectric performance and anomalous Seebeck effects in topological insulators. Phys Rev Lett, 2014, 112: 226801

14 Wang J, Xu Y, Zhang S C. Two-dimensional time-reversal-invariant topological superconductivity in a doped quantum spin-Hall insulator. Phys Rev B, 2014, 90: 054503

15 Wu S C, Shan G, Yan B H. Prediction of near-room-temperature quantum anomalous Hall effect on honeycomb materials. Phys Rev Lett, 2014, 113: 256401

16 Tang P, Chen P, Cao W, et al. Stable two-dimensional dumbbell stanene: A quantum spin Hall insulator. Phys Rev B, 2014, 90: $121408(\mathrm{R})$

17 Saxena S, Choudhary R, Shukla S. Stanene: Atomically thick free-standing layer of 2D hexagonal tin. 2015, arxiv: 1505.05062

18 Eguchi T, Nakamure J, Osaka T. Structure and electronic states of the $\alpha$-Sn(111)-(2×2) surface. J Phys Soc Jpn, 1998, 67: 381

19 Fantini P, Gardonio S, Barbieri P, et al. $\alpha$-Sn pseudomorphic growth on InSb(111) and (111) surfaces: A high-resolution photoemission study. Surf Sci, 2000, 463: 174

20 Barfuss A, Dudy L, Scholz M R, et al. Elemental topological insulator with tunable Fermi level: Strained $\alpha$-Sn on InSb(001). Phys Rev Lett, 2013, 111: 157205

21 Zhu F F, Chen W J, Xu Y, et al. Epitaxial growth of two-dimensional stanene. Nat Mater, 2015, 14: 1020

22 Gao J F, Zhang G, Zhang Y W. Exploring Ag(111) substrate for epitaxially growing monolayer stanene: A first-principles study. Sci Rep, 2016, 6: 29107

23 Tao L, Cinquanta E, Chiappe E, et al. Silicene field-effect transistors operating at room temperature. Nat Nano, 2015, 10: 227

24 Liu X H, Wang Y, Li F, et al. Two-dimensional stanane: strain-tunable electronic structure, high carrier mobility, and pronounced light absorption. Phys Chem Chem Phys, 2016, 18: 14638

25 Xiong W Q, Xia C, Wang T, et al. Strain and spin-orbital coupling effects on electronic structures and magnetism of semi-hydrogenated stanene. J Phys Chem C, 2016, 120: 10622

26 Shaidu Y, Akin-Ojo O. First principles predictions of superconductivity in doped stanene. Comp Mater Sci, 2016, 118: 11

27 Peng B, Zhang H, Shao H, et al. Low lattice thermal conductivity of stanene. Sci Rep, 2016, 6: 20225

28 Nissimagoudar A S, Manjanath A, Singh A. Diffusive nature of thermal transport in stanene. Phys Chem Chem Phys, 2016, 18: 14257

29 Gu X, Yang R. First-principles prediction of phononic thermal conductivity of silicene: A comparison with graphene. J Appl Phys, 2015, 117: 025102

30 Peng B, Zhang H, Shao H, et al. Thermal conductivity of monolayer $\mathrm{MoS}_{2}$, $\mathrm{MoSe}_{2}$, and $\mathrm{WS}_{2}$ : Interplay of mass effect, interatomic bonding and anharmonicity. RSC Adv, 2016, 6: 5767

31 Xu Y, Tang P, Zhang S C. Large-gap quantum spin Hall states in decorated stanene grown on a substrate. Phys Rev B, 2015, 92: 081112(R)

32 Ding Y, Wang Y L. Quasi-free-standing features of stanene/stanane on InSe and GaTe nanosheets: A computational study. J Phys Chem, 2015, 119: 27848

33 Wang D C, Chen L, Wang X L, et al. The effect of substrate and external strain on electronic structures of stanene film. Phys Chem Chem Phys, 2015, 17: 26979 


\title{
Recent progress in the study of stanene
}

\author{
QIAN Dong \& JIA JinFeng \\ Department of Physics and Astronomy, Shanghai Jiao Tong University, Shanghai 200240, China
}

Inspired by the successfully experimental realization of graphene, other ultrathin materials consisting of group-IV elements $\mathrm{Si}, \mathrm{Ge}$ and $\mathrm{Sn}$ have been attracted plenty of interests due to their unprecedented electronic properties. Among them, two-dimensional low-buckled Sn-based stanene and its derivatives present novel quantum properties due to its large spin-orbital coupling, such as a quantum spin Hall insulating behaviour with a very large band gap, and the capability to support enhanced thermoelectric performance, topological superconductivity and the near-room-temperature quantum anomalous Hall effect and so on. Therefore, stanene shows the great application potentials in the dissipationless electric conduction at room temperature, high performance thermoelectricity, spintronics and topological quantum computation. This review will briefly introduce the recent progress in the study of stanene both in theory and in experiment.

Firstly, we will discuss the main motivation on study of the stanene. Tin $(\mathrm{Sn})$ is a heavy element and stanene has the low-buckled honeycomb-like crystal structure, which makes its spin-orbital coupling strong enough to realize a quantum spin Hall state with a large energy gap of about $0.1 \mathrm{eV}$. The large bulk gap makes stanene the excellent candidate to explore the topological quantum properties of a quantum spin Hall insulator above the cryogenic temperature.

Secondly, we will briefly introduce the theoretical calculations or predictions of the crystal and electronic structures of stanene. First-principle calculations show that the honeycomb-like low-buckled crystal structure of two-dimensional stanene is stable and could be realized experimentally in principle. Due to the $\mathrm{sp}^{3}$ orbitals in stanene, it has dangling bonds that can be modified by surface decoration. Long range ferromagnetic order, topological superconductivity and largely enhanced bulk energy gap (up to $\sim 0.3 \mathrm{eV}$ ) can be achieved by proper surface decoration theoretically. Topological transition can also induced by hydrogen absorption.

Thirdly, we will discuss the first experimental realization of the monolayer stanene films with low-buckled crystal structure using molecular beam epitaxy method on the $\mathrm{Bi}_{2} \mathrm{Te}_{3}$ single crystalline substrates, which brings the stanene to the real word and inspires more and more theoretical predictions. The crystal structure of epitaxial growth stanene was determined by scanning tunneling spectroscopy and its electronic structure was measured by angle-resolved photoemission spectroscopy. Due to the charge transfer between the epitaxial stanene and the $\mathrm{Bi}_{2} \mathrm{Te}_{3}$ substrate, stanene film on $\mathrm{Bi}_{2} \mathrm{Te}_{3}$ is not an insulator. It is hole-doped.

At last, we will introduce some very recent theoretical works on how to improve stanene films beyond the current experimental achievements. Based on new proposals, new experiments could be done on the stanene films. For example, new substrate has been proposed by first-principle calculations to get high-quality stanene films with much larger area; other quantum orders such as ferromagnetism and superconductivity can be realized through surface decoration or electron doping, which can be tested using low-temperature scanning tunneling spectroscopy. Very low thermal conductivity was founded in theory in stanene, which is another very interesting experiment. Finally, new insulating substrates has been suggested by first-principle calculations to obtain insulating stanene films that can be used to study the electric transport properties of the topological one-dimensional edge states. More experiments could be carried out along this direction.

stanene, large band gap, quantum-spin-Hall-effect insulator, molecular beam epitaxy

doi: $10.1360 / \mathrm{N} 972016-00681$ 